\title{
West Nile virus encephalitis in GATA2 deficiency
}

\author{
Jaime S. Rosa ${ }^{1 *}$, Shanthi Kappagoda ${ }^{2}$, Amy P. Hsu³ ${ }^{3}$ Joie Davis ${ }^{3}$, Steven M. Holland ${ }^{3}$ and Anne Y. Liu ${ }^{1,2}$
}

\begin{abstract}
We report a male with longstanding warts who presented with severe West Nile virus encephalitis (WNVE) and recovered after interferon alfa-2b and intravenous immunoglobulin. He was later found to have GATA2 deficiency and underwent successful hematopoietic stem cell transplant.
\end{abstract}

Keywords: West Nile virus, Encephalitis, GATA2, Interferon, Immunoglobulin

\section{Introduction}

A 24-year-old Caucasian male beekeeper was admitted for altered mental status. Within the past 2 weeks during the month of August, he had been camping in Wyoming, where he and his companions suffered from mosquito bites. All of them had rashes that resolved after 3 days, but our patient subsequently developed worsening fevers, headache, confusion, abdominal pain, vomiting, and diarrhea. MRI of the brain showed T2-signal hyperintensities within the deep white matter. Electroencephalography was normal but lumbar puncture revealed pleocytosis, consistent with CNS infection (Table 1). He was started on vancomycin, ceftriaxone, doxycycline, acyclovir, and dexamethasone empirically and was transferred to the intensive care unit. This patient was agitated and unable to follow instructions. CSF West Nile virus (WNV) IgM and serum WNV IgM and RNA were detectable while the remainder of the infectious workup was negative. Peripheral blood flow cytometry demonstrated pancytopenia with complete absence of monocytes (Table 1); lymphocytes were markedly decreased, including CD16+56+natural killer (NK) cells and CD56 ${ }^{\text {bright }} \mathrm{CD} 16+\mathrm{NK}$ cells. NK cell cytotoxicity assay was normal.

The patient's childhood history included rosacea and intermittent left foot swelling occurring once a year.

\footnotetext{
*Correspondence: jsr@iname.com

${ }^{1}$ Division of Allergy, Immunology, and Rheumatology, Department of Pediatrics, Stanford University School of Medicine, 269 Campus Drive, CCSR 3215, MC 5366, Stanford, CA 94305, USA

Full list of author information is available at the end of the article
}

Beginning age 7, he developed warts on his hands, feet, digits, and limbs that recurred despite multiple attempts at removal. He suffered multiple episodes of pneumonia, bronchitis, and sinusitis. At age 18, he was referred to a hematologist for persistent leukopenia and intermittent thrombocytopenia (Table 1). Bone marrow aspirate and biopsy showed reduced myeloid precursors, with marked left shift and megakaryocyte reduction, which was interpreted as possible evolving aplastic anemia. Family history was notable for brain abscess in his father. His father and paternal grandfather died in their late $40 \mathrm{~s}$ from influenza pneumonia.

To treat his WNVE, he received $400 \mathrm{mg} / \mathrm{kg}$ intravenous immunoglobulin (IVIG) daily for 3 consecutive days (high titer WNV immunoglobulin was not available). Based on his profile of longstanding warts due to human papillomavirus (HPV), recurrent sinopulmonary infections and lymphedema, absent circulating monocytes and significant lymphopenia, marrow hypoplasia, a paternal family history of deaths from viral illnesses, and now life-threatening WNVE, the diagnosis of GATA2 deficiency with impaired antiviral immunity was suspected. Therefore, he received 3 million units of subcutaneous interferon alfa-2b daily for 14 days [1]. Two days after starting the interferon alfa- $2 \mathrm{~b}$, his warts and neurocognitive function improved (Fig. 1). The patient became fully cooperative and oriented, but he still had some residual poor balance, scissoring gait, and mild flu-like symptoms. The patient was discharged to a rehabilitation facility on day 14 of hospitalization and then home. 
Table 1 Laboratory testing results at different time periods of this patient's presentation

\begin{tabular}{|c|c|c|c|}
\hline Laboratory testing & $\begin{array}{l}\text { Six years prior to WNVE } \\
\text { presentation }\end{array}$ & Current presentation & Normal ranges \\
\hline \multicolumn{4}{|l|}{ Peripheral blood and serum } \\
\hline White blood cells (cells/ $\mu \mathrm{L}$ ) & 1800 & 2100 & $(4500-13,000)$ \\
\hline Neutrophils (cells/ $\mu \mathrm{L}$ ) & 1062 & 1810 & $(1800-8000)$ \\
\hline Lymphocytes (cells/ $\mu \mathrm{L}$ ) & 702 & 270 & $(1200-5200)$ \\
\hline Monocytes (cells/ $\mu \mathrm{L})$ & 18 & 0 & $(200-900)$ \\
\hline Eosinophils (cells/ $\mu \mathrm{L}$ ) & 18 & 10 & $(15-500)$ \\
\hline Basophils (cells/ $\mu \mathrm{L}$ ) & 18 & 0 & $(0-200)$ \\
\hline Platelets (cells/ $\mu \mathrm{L}$ ) & 184,000 & 103,000 & $(140,000-400,000)$ \\
\hline Hemoglobin (g/L) & 12.7 & 11.3 & $(12.0-16.9)$ \\
\hline Hematocrit (\%) & 36.8 & 32.0 & $(36.0-49.0)$ \\
\hline CD3 T lymphocytes (cells/ $\mu \mathrm{L}$ ) & NM & 288 & $(700-2100)$ \\
\hline CD4 T lymphocytes (cells/ $\mu \mathrm{L}$ ) & NM & 161 & $(300-1400)$ \\
\hline CD8 T lymphocytes (cells/ $\mu \mathrm{L}$ ) & NM & 68 & $(200-900)$ \\
\hline CD56+16 NK lymphocytes (cells/ $\mu \mathrm{L}$ ) & NM & 13 & $(90-600)$ \\
\hline CD19 B lymphocytes (cells/ $\mu \mathrm{L}$ ) & NM & 8 & $(100-500)$ \\
\hline $\lg G$ & 3100 & 2180 & $(694-1618)$ \\
\hline $\lg G_{1}$ & 2340 & 1780 & $(382-929)$ \\
\hline $\operatorname{lgG}_{2}$ & 397 & 203 & $(241-700)$ \\
\hline $\lg _{3}$ & 323 & 140 & $(22-178)$ \\
\hline $\operatorname{lgG}_{4}$ & 2.2 & 2.2 & $(4-48)$ \\
\hline $\lg A$ & 329 & 217 & $(81-463)$ \\
\hline $\lg M$ & 101 & 66 & $(48-271)$ \\
\hline \multicolumn{4}{|l|}{ Cerebrospinal fluid } \\
\hline CSF: White blood cells (cells $/ \mu \mathrm{L}$ ) & NM & 8 & $(0-5)$ \\
\hline CSF: Polymorphonuclear cells (cells/ $\mu \mathrm{L}$ ) & NM & 5 & $(0)$ \\
\hline CSF: Mononuclear cells (cells/ $\mu \mathrm{L}$ ) & NM & 3 & $(0-5)$ \\
\hline CSF: Red blood cells (cells/ $\mu \mathrm{L}$ ) & NM & 3 & $(0-10)$ \\
\hline
\end{tabular}

HPF high power field, NM not measured

DNA sequencing showed a heterozygous single base deletion in GATA2, c.1021delG, causing p.A341Pfs, eliminating the highly conserved second zinc finger

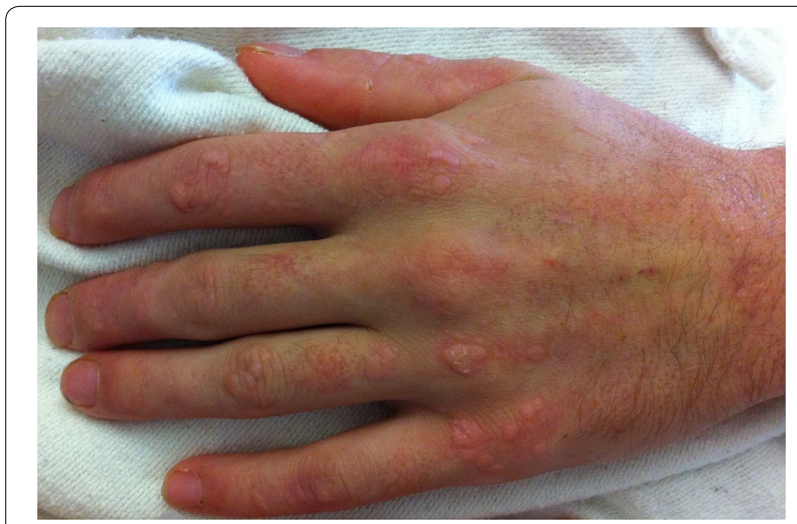

Fig. 1 The patient was started on interferon alfa-2b. Within a few days, his warts subsided and his neurocognitive function showed significant improvement of GATA2. His mother did not carry the mutation, and paternal DNA was not available for sequencing. Two years after his encephalitis, he underwent a haploidentical hematopoietic stem cell transplant (HSCT) from his mother following conditioning with fludarabine, cyclophosphamide, busulfan, and total body irradiation. His course was complicated by persistent verrucae and cutaneous graft-versus-host disease.

\section{Discussion}

The transcription factor, GATA2, is a master regulator of hematopoietic development and maintenance of the healthy stem cell pool. It recognizes the DNA motif, $(\mathrm{A} / \mathrm{T})$ GATA(A/G), using its two zinc-finger domains [2, 3]. GATA2 deficiency (also known as monocytopenia with mycobacterial disease (MonoMAC); dendritic cell (DC), myeloid, and NK cell lymphopenia (DCML); lymphedema and myelodysplasia (Emberger syndrome); and familial myelodysplasia/leukemia) is due to heterozygous 
germline mutations. Patients with mutations in this gene can present with highly variable phenotypes including cytopenias, myelodysplasia, acute myeloid leukemia, other hematologic and solid neoplasms, pulmonary alveolar proteinosis, thrombosis, lymphedema, sensorineural hearing loss, panniculitis, and other autoimmune disorders [3]. Recurrent infections due to viruses (such as HPV, EBV, $\mathrm{HSV}$, and VZV), nontuberculous mycobacteria, and fungi are common [3].

WNVE primarily occurs in elderly and immunocompromised patients, related to reduced viral control. Our patient's experience suggested that his genetic defect, with its associated NK, T and B lymphopenias, predisposed him to severe WNVE. Despite normal NK function in vitro, he had profound reductions in total and $\mathrm{CD} 56^{\text {bright }} \mathrm{CD} 16+\mathrm{NK}$ cells. His NK cells were comprised almost exclusively of the CD56 ${ }^{\mathrm{dim}} \mathrm{CD} 16+$ subset, similar to the NK cell profiles reported previously in GATA2 deficiency [4].

Use of interferon alfa-2b and IVIG had been reported in immunocompetent hosts with WNVE, some of whom subsequently recovered. However, their therapeutic roles in WNV infections are still not completely clear. Interferons are glycopeptides with immunoregulatory, antiviral, and antitumor activities with clinical applications in viral hepatitis and chronic myeloid leukemia, among other uses [5]. The addition of interferon alpha- $2 \mathrm{~b}$ in primate cell cultures before and after WNV inoculation reduced viral cytotoxicity, manifested as a recovery of cellular proliferative capacity [6]. IFN- $\alpha / \beta$ receptor-deficient mice infected with WNV also had less serum viral clearance and higher mortality, showing a possible protective role for type I interferons in WNV immunity [7]. A small study had previously suggested that immunoglobulins from donor populations with a higher prevalence of WNV exposures might contain WNV neutralizing antibody titers [8]. While the use of interferon alfa- $2 b$ and IVIG in human WNVE is limited to only a few case reports with mixed outcomes, in view of his life-threatening infection and likely underlying defect, including clearly impaired antiviral immunity as manifested by chronic HPV infection, we felt that they might have benefits $[1,9]$.

Currently, HSCT is the only curative option for GATA2 deficiency [10]. Case series have reported success rates ranging from $\sim 50$ to $86 \%$ with a median follow-up of $3.5-5$ years [10]. Given the wide range of phenotypes, age at presentation and diagnosis, disease severity and rate of progression, and the risk of serious infection, as in this case, or development of leukemia, early pursuit of HSCT is reasonable. While there are variable opportunities for complete HLA matching, research is ongoing to identify the optimal conditioning and graft versus host prevention regimens for these patients.
This is the first report of a patient with GATA2 deficiency and severe WNVE. While prospective data on the management of invasive WNVE are lacking, our patient tolerated immunoglobulin and interferon alfa- $2 \mathrm{~b}$ with good clinical response.

\section{Authors' contributions}

JSR, SK, and AYL were involved in the clinical care and interpretation of results. $\mathrm{APH}, \mathrm{JD}$, and SMH were involved in the laboratory workup and interpretation of results. All authors edited. All authors read and approved the final manuscript.

\section{Author details}

${ }^{1}$ Division of Allergy, Immunology, and Rheumatology, Department of Pediatrics, Stanford University School of Medicine, 269 Campus Drive, CCSR 3215, MC 5366, Stanford, CA 94305, USA. ${ }^{2}$ Division of Infectious Diseases and Geographic Medicine, Department of Medicine, Stanford University School of Medicine, Stanford, CA 94305, USA. ${ }^{3}$ Laboratory of Clinical Immunology and Microbiology, National Institute of Allergy and Infectious Diseases, National Institutes of Health, Bethesda, MD 20892, USA.

\section{Competing interests}

The authors declare that they have no competing interests.

\section{Availability of data and materials}

The datasets supporting the conclusions of this article are included in the article and in its additional files (Table 1; Fig. 1).

\section{Consent for publication}

Written consent to publish this report was obtained from the patient. A copy can be made available if required.

\section{Ethics approval and consent to participate}

Written consent to publish this report was obtained from the patient. A copy can be made available if required.

\section{Funding}

No external funding was obtained.

\section{Publisher's Note}

Springer Nature remains neutral with regard to jurisdictional claims in published maps and institutional affiliations.

Received: 30 October 2018 Accepted: 10 January 2019

Published online: 24 January 2019

\section{References}

1. Kalil AC, Devetten MP, Singh S, Lesiak B, Poage DP, Bargenquast K, et al. Use of interferon-alpha in patients with West Nile encephalitis: report of 2 cases. Clin Infect Dis. 2005:40(5):764-6.

2. Hsu AP, Sampaio EP, Khan J, Calvo KR, Lemieux JE, Patel SY, et al. Mutations in GATA2 are associated with the autosomal dominant and sporadic monocytopenia and mycobacterial infection (MonoMAC) syndrome. Blood. 2011:118(10):2653-5.

3. Spinner MA, Sanchez LA, Hsu AP, Shaw PA, Zerbe CS, Calvo KR, et al. GATA2 deficiency: a protean disorder of hematopoiesis, lymphatics, and immunity. Blood. 2014;123(6):809-21.

4. Mace EM, Hsu AP, Monaco-Shawver L, Makedonas G, Rosen JB, Dropulic $L$, et al. Mutations in GATA2 cause human NK cell deficiency with specific loss of the CD56(bright) subset. Blood. 2013;121(14):2669-77.

5. Chou R, Hartung D, Rahman B, Wasson N, Cottrell EB, Fu R. Comparative effectiveness of antiviral treatment for hepatitis $C$ virus infection in adults: a systematic review. Ann Intern Med. 2013;158(2):114-23.

6. Anderson JF, Rahal JJ. Efficacy of interferon $a-2 b$ and ribavirin against West Nile virus in vitro. Emerg Infect Dis. 2002;8(1):107-8. 
7. Samuel MA, Diamond MS. Alpha/beta interferon protects against lethal West Nile virus infection by restricting cellular tropism and enhancing neuronal survival. J Virol. 2005;79(21):13350-61.

8. Ben-Nathan D, Lustig S, Tam G, Robinzon S, Segal S, Rager-Zisman B. Prophylactic and therapeutic efficacy of human intravenous immunoglobulin in treating West Nile virus infection in mice. J Infect Dis. 2003;188(1):5-12.
9. Walid MS, Mahmoud FA. Successful treatment with intravenous immunoglobulin of acute flaccid paralysis caused by west nile virus. Perm J. 2009;13(3):43-6.

10. Parta M, Shah NN, Baird K, Rafei H, Calvo KR, Hughes T, et al. Allogeneic hematopoietic stem cell transplantation for GATA2 deficiency using a busulfan-based regimen. Biol Blood Marrow Transplant. 2018;24(6):1250-9.
Ready to submit your research? Choose BMC and benefit from:

- fast, convenient online submission

- thorough peer review by experienced researchers in your field

- rapid publication on acceptance

- support for research data, including large and complex data types

- gold Open Access which fosters wider collaboration and increased citations

- maximum visibility for your research: over $100 \mathrm{M}$ website views per year

At BMC, research is always in progress.

Learn more biomedcentral.com/submissions 